\title{
COVID-19. The other side of the coin
}

Viebig RG. COVID-19. The other side of the coin. Arq Gastroenterol. 2020;57(2):113.

The pandemic is changing the world in many ways. There is no doubt what evils have been causing not only on people's physical health, but also on their spirit, customs, social organization and the current and as well as in the future way of living. On the other hand, it has sharpened the curious spirit of physicians and researchers in the search for treatment solutions, such as vaccines, antiviral drugs and solutions to control the contagion of this and future events. Terms such as social isolation, lockdown, curve flattening, are part of family and social conversations. Social networks are full of information. Because of social isolation, conversations via apps are intense. False information, technical information, epidemiological concepts, research methods and dissemination of statistics burst like popcorn and there is countless information we receive every day. Many controversial and others completely opposed.

A scientific journal representing the gastroenterological community of Brazil, Latin American countries and other emerging countries, had a noteworthy change since March of this year: a significant increase in submissions $(50 \%)$, until the month of May, compared to previous years ${ }^{(1)}$.

To interpret this fact, I could not resort to a specific questionnaire, but I would like to share an imaginative exercise. Some hypotheses for this phenomenon arose: First, the pandemic allowed more time for papers that were hibernating, to be reactivated and submitted. Second, with more time left due to the decrease in didactic activities, there was a redirection of these to the production of data and texts. A third hypothesis would be that the researcher and his collaborators who in their daily activity are slaves of time, when they were free of other physical and face-to-face tasks, were able to produce intellectual work and conduct research that was projected or that emerged from the moment their thought became free from other attributions.

Anyway, I feel happy as an editor, to see this productivity increasing. I'm worried there won't be a hangover and scientific production will decline. I believe that the new NORMALITY will not allow this setback.
The world has awakened to the importance of science in every way. There was no forecasted calculations for a pandemic like this. There were not enough studies for the treatment and containment of a virus like this, despite previous epidemics such as SARS, ebola, etc. There are many problems still in the world that require active and dedicated researchers.

There is a huge effort of governments to establish strategies to care for the population, from the simplest symptoms, to cases that require technological complexity and specialized professional knowledge in view of the severity condition of the patient. May these warnings will be maintained and that this pandemic will serve as a lesson in what humanity's priorities are. The structures set up for the care of the population be absorbed by health systems around the world, because there was not even a nation that did not have to readjust.

Finally, it is hoped that the sum of efforts resulting from all these actions can produce knowledge and that it be made available to all. May the truths be told and the lies quickly wiped out. May the interests of the human race be above individual interests or the exercise of power. That the researcher's work is valued and, that they have possibilities to produce better and that they have freedom to disseminate their discoveries and doubts, producing an exchange of knowledge, (just as we are doing), good or bad, through social networks or the like.

For our part, we will continue linked to the ideas proposed by the editors, reviewers and collaborators of this journal: to disseminate science in a complete way, with open access and at no cost to the researchers. This is the mission of the Archives of Gastroenterology and their maintaining entities, Hospital IGESP and Brazilian Institute for Studies and Research in Gastroenterology (IBEPEGE).

Viebig RG. COVID-19. O outro lado da moeda. Arq Gastroenterol. 2020;57(2):113.

\section{REFERENCE}

1. Scimago Journal \& Country Rank. [Internet]. [Access 2020 May 24]. Available from: https://www.scimagojr.com/journalsearch.php?q=28247\&tip=sid\&clean=0

Corresponding author: Ricardo Guilherme Viebig. Hospital IGESP, Motilidade Digestiva e Neurogastroenterologia (MoDiNe), São Paulo, SP, Brasil. ORCID: 0000-0002-6541-0401. E-mail: rviebig@gmail.com 